\title{
Caenorhabditis elegans sex-determining protein FEM-2 is a protein phosphatase that promotes male development and interacts directly with FEM-3
}

\author{
Ian D. Chin-Sang and Andrew M. Spence ${ }^{1}$ \\ Department of Molecular and Medical Genetics, University of Toronto, Toronto, Ontario, Canada, M5S 1A8
}

\begin{abstract}
Male sexual development in the nematode Caenorhabditis elegans requires the genes fem-1, fem-2, and fem-3. The current model of sex determination portrays the FEM proteins as components of a novel signal transduction pathway, but the mechanisms involved in signaling through the pathway are not understood. We report the isolation of fem-2 cDNAs in a yeast two-hybrid screen for clones encoding proteins that interact with FEM-3. Association of FEM-3 and FEM-2 in two independent in vitro binding assays substantiates the interaction detected in the two-hybrid system. FEM-2 is related in sequence to protein serine/threonine phosphatases of Type 2C (PP2C). We demonstrate that FEM-2 exhibits magnesium-dependent casein phosphatase activity, typical of PP2C, in vitro. Point mutations that abolish the casein phosphatase activity of FEM-2 without affecting its FEM-3-binding activity reduce severely its ability to rescue male development in fem-2 mutant nematodes. These results suggest that protein phosphorylation regulates sex determination in $C$. elegans.
\end{abstract}

[Key Words: Signal transduction; PP2C; development; protein interaction; phosphorylation; two-hybrid]

Received April 22, 1996; revised version accepted July 26, 1996.

The nematode Caenorhabditis elegans normally develops as either a self-fertile hermaphrodite or a male. Male development of both germ-line and somatic tissues requires three genes known as fem-1, fem-2, and fem-3. Mutants that lack the activity of any one of the fem genes develop as true females that differ from hermaphrodites only in that they do not produce any sperm (Doniach and Hodgkin 1984; Hodgkin 1986).

The primary sex-determining signal, which regulates the masculinizing activity of the fem genes, is the relative number of $\mathrm{X}$ chromosomes and sets of autosomes, known as the X/A ratio (Madl and Herman 1979). In diploid strains of $C$. elegans, males have one $\mathrm{X}$ chromosome $(\mathrm{XO} ; \mathrm{X} / \mathrm{A}$ ratio of 0.5$)$, whereas hermaphrodites have two $(\mathrm{XX} ; \mathrm{X} / \mathrm{A}$ ratio of 1.0$)$. The effect of the $\mathrm{X} / \mathrm{A}$ ratio upon fem activity is indirect, involving a well-studied cascade of genetic interactions. A simplified form of that cascade is outlined in Figure 1A. The first portion, including the genes $x o l-1$ and $s d c-1, s d c-2$, and $s d c-3$, controls both sex determination and X chromosome dosage compensation. Control of these two processes diverges at the level of the $s d c$ genes, and the remainder of the cascade shown in Figure 1A regulates sex determination exclusively (for review, see Hodgkin 1988; Villeneuve and Meyer 1990a).

${ }^{1}$ Corresponding author.
Genetic mosaic analyses suggested that sex determination in C. elegans involves cell-cell communication (Villeneuve and Meyer 1990b; Hunter and Wood 1992). Molecular analysis supports a model of the sex-determining cascade as a cell-cell signaling pathway (Fig. 1B) in which the products of the fem genes act as signaltransducing molecules (for review, see Hodgkin 1992; Kuwabara and Kimble 1992). In XO animals, the low $\mathrm{X} / \mathrm{A}$ ratio causes transcriptional derepression of her-1 (Trent et al. 1991; Perry et al. 1993). The predicted product of her-1 (HER-1) is a small cysteine-rich protein with a secretion signal sequence that is essential for its activity (Perry et al. 1993). HER-1 negatively regulates a predicted transmembrane protein encoded by tra-2 (TRA2A), perhaps by means of a direct ligand-receptor interaction (Kuwabara et al. 1992). TRA-2A is a negative regulator of at least one of the predicted intracellular proteins (FEM-1, FEM-2, and FEM-3) encoded by the fem genes (Spence et al. 1990; Ahringer et al. 1992; Kuwabara and Kimble 1995; Pilgrim et al. 1995|. HER-1-mediated inactivation of TRA-2A relieves the negative regulation of the FEM proteins, and they in turn bring about male somatic development by negatively regulating the products of tra-1, one of which (TRA-1A) is a sequence-specific DNA-binding protein (Zarkower and Hodgkin 1992, 1993). The FEM proteins are essential for spermatogenesis even in the absence of tra-1 activity, indicating that 
A

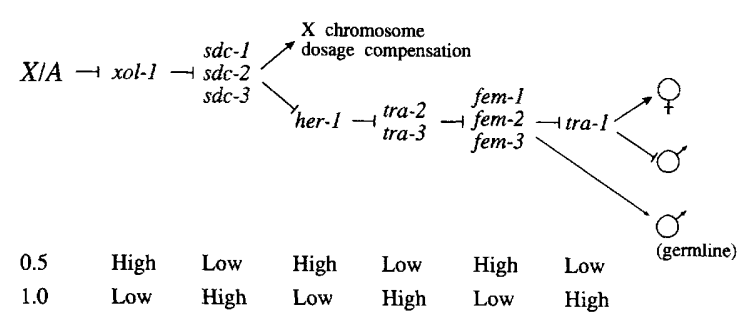

B

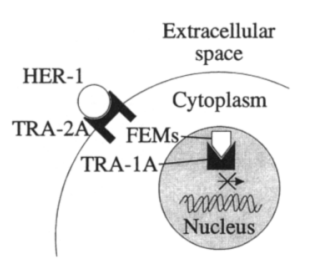

Xo

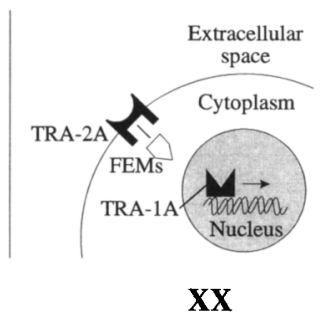

$\mathrm{XX}$
Figure 1. Model of somatic sex determination in C. elegans. (A) Genetic interactions between genes required for somatic sex determination. (Barred lines) Negative interactions; (arrows) positive interactions. The $\mathrm{X} / \mathrm{A}$ ratio controls both $\mathrm{X}$ chromosome dosage compensation and sex determination via xol-1 and the $s d c$ genes (Villeneuve and Meyer 1990a). The regulatory pathway branches at the level of the $s d c$ genes, and only the branch that controls somatic sex determination is shown. A low $\mathrm{X} / \mathrm{A}$ ratio results in elevated activity of her-1 and the fem genes, which bring about male development by regulating tra-1 negatively. The fem genes have additional targets in the germ-line, because they are required for spermatogenesis irrespective of the state of tra-1. (B) Speculative molecular model of somatic sex determination. (Left) A low X/A ratio results in the synthesis of HER-1, a small, secreted protein that inactivates the membrane protein TRA-2A, thereby releasing the cytoplasmic FEM proteins from negative regulation. The FEM proteins then inhibit the activity of the sequence-specific DNA-binding protein, TRA-1A, by an unknown mechanism to cause male development. (Right) A high X/A ratio prevents HER-1 synthesis, allowing TRA-2A to inhibit the FEM proteins and TRA-1A to direct female somatic development.

they also have other, germ-line-specific targets (Doniach and Hodgkin 1984; Hodgkin 1986). Candidates for such targets include the products of the genes fog- 1 and $f_{0 g}-3$, which are specifically required for spermatogenesis (Barton and Kimble 1990; Ellis and Kimble 1995).

Ignorance of the interactions and activities of the FEM proteins presently obscures the biochemical mechanism that transduces the sex-determining signal from HER-1 to TRA-1. Whether the FEM proteins act sequentially to elaborate a single regulatory activity, interact to form a regulatory complex, or employ independent, nonredundant regulatory mechanisms remains unknown. Their predicted sequences provide few clues as to their mechanisms of action. FEM-1 contains six copies of the cdc10-Swi6 (or ANK) motif, which in many other proteins mediates specific protein-protein interactions (Spence et al. 1990; Michaely and Bennett 1992). FEM-3 is a key target of regulation in the germ-line (Barton et al. 1987; Ahringer and Kimble 1991) and in somatic tissues (A. Mehra, L. Heck, P. Kuwabara, and A.M. Spence, in prep.), but its sequence is novel and provides no hint of its activity (Ahringer et al. 1992). With the view that the identification of FEM-3-interacting proteins would provide a starting point for investigating signal transduction in the sex determination pathway, we performed a twohybrid screen (Fields and Song 1989; Durfee et al. 1993) for cDNAs that encode such proteins. In this paper, we report that FEM-3 interacts with FEM-2. The sequence of fem-2, reported recently by Pilgrim et al. (1995), predicts that FEM-2 is related in sequence to protein serine/threonine phosphatases of Type $2 \mathrm{C}$. We show that FEM-2 is active as a protein phosphatase, and that its phosphatase activity is necessary for its role in promoting male development.

\section{Results}

\section{FEM-3 and FEM-2 interact in the yeast two-hybrid} system

We used the yeast two-hybrid system (Fields and Song 1989; Durfee et al. 1993) to identify genes encoding proteins that interact with FEM-3. A fusion protein consisting of FEM-3 and the DNA-binding domain of GAL4 (GAL4DB-FEM-3) served to screen a C. elegans cDNA library encoding fusion proteins containing the GAL4 activation domain (GAL4AD). Among 2.3 million yeast transformants bearing the plasmid encoding GAL4DBFEM-3 and a library plasmid, we identified twenty that expressed HIS 3 and lacZ reporter genes under the control of the GAL4 binding site, UAS ${ }_{\mathrm{G}}$. Three transformants carried library plasmids that activated reporter gene expression only in the presence of GAL4DBFEM-3.

DNA sequence analysis revealed that two of these three plasmids carry cDNAs from the sex-determining gene fem-2, the sequence of which was recently reported by Pilgrim et al. (1995). The third interacting clone will be described elsewhere. The fem-2 cDNAs isolated in our screen differ only in the extent of the 3 ' untranslated sequence they include; both encode full-length FEM-2, consisting of 449 amino acid residues. Interaction between GAL4DB-FEM-3 and GAL4AD-FEM-2 in the yeast two-hybrid system stimulates the expression of a $\mathrm{UAS}_{\mathrm{G}}-1 a c Z$ reporter gene 200-fold above background (Table 1). Neither fusion protein stimulates reporter gene expression when expressed alone or with a control fusion protein containing the complementary GAL4 domain.

Genetic studies have established that fem-2 and fem-3 function at the same level in the sex-determining pathway (Doniach and Hodgkin 1984; Kimble et al. 1984; Hodgkin 1986) (Fig. 1A), but previous work has not provided evidence of direct interactions between the products of the fem genes. To substantiate the interaction detected in the two-hybrid system, we tested for association between FEM-2 and FEM-3 in in vitro binding assays. 
Table 1. Interaction of FEM-3 and FEM-2 in the yeast two-hybrid system

\begin{tabular}{lccc}
\hline & $\begin{array}{l}\text { Activation } \\
\text { domain }\end{array} \begin{array}{c}\text { DNA-binding } \\
\text { domain fusion }\end{array}$ & \multicolumn{2}{c}{$\begin{array}{c}\text { Relative - } \beta \text {-galactosidase } \\
\text { activity }^{\mathbf{a}}\end{array}$} \\
\cline { 3 - 4 } fusion & - & mean & range \\
\hline FEM-3 & SNF4 & 0.7 & $0.5-0.9$ \\
- & FEM-2 & 0.7 & $0.5-0.9$ \\
FEM-3 & SNF4 & 1.0 & $0.5-1.0$ \\
FEM-3 & FEM-2 & 200 & $0.6-1.4$ \\
\hline
\end{tabular}

${ }^{a} \beta$-galactosidase activity was measured in liquid cultures of at least three independent transformants. Activity was normalized to the activity resulting from coexpression of a FEM-3 DNAbinding domain fusion and a SNF4 activation domain fusion.

\section{Association of FEM-2 and FEM-3 in vitro}

Two assays provided biochemical evidence for a proteinprotein interaction between FEM-2 and FEM-3. In the first, we carried out coupled in vitro transcription and translation of fem-2 cDNA, either alone or together with a clone directing the synthesis of a Myc epitope-tagged derivative of FEM-3 (Myc-FEM-3). We then tested the ability of the monoclonal antibody 9E10, which recognizes the Myc epitope (Evan et al. 1985), to immunoprecipitate the reaction products. The antibody exhibited no reactivity toward FEM-2 alone, but it coprecipitated FEM-2 and Myc-FEM-3 from reactions containing both proteins (Fig. 2).

In an independent test of the ability of FEM-2 to bind to FEM-3, we produced FEM-2 in E. coli as a soluble glutathione $S$-transferase fusion protein (GST-FEM-2). We bound GST-FEM-2 to glutathione-Sepharose and used it as a ligand for batch affinity chromatography of in vitro translation reactions containing ${ }^{35}$ S-Myc-FEM-3. FEM-3 bound specifically to immobilized GST-FEM-2

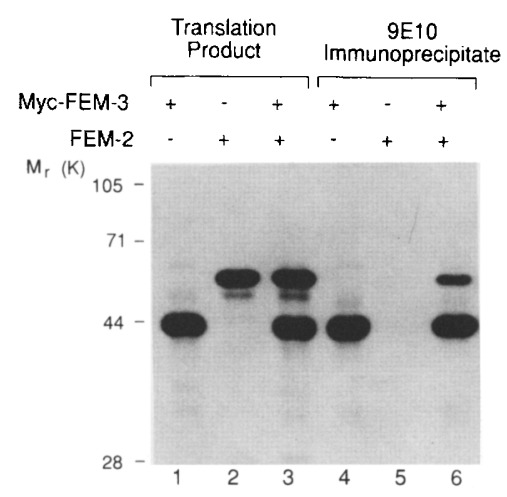

Figure 2. Coimmunoprecipitation of FEM-2 with Myc-FEM-3. ${ }^{35}$ S-labeled Myc-FEM-3 (lane 1), FEM-2 (lane 2), or both MycFEM-3 and FEM-2 (lane 3), synthesized by in vitro translation in reticulocyte lysates. Lanes 4-6 display proteins immunoprecipitated with anti-Myc monoclonal antibody $9 E 10$ from the translation reactions shown in lanes $1-3$, respectively. Proteins were analyzed by SDS-PAGE and fluorography. and not to immobilized GST (Fig. 3). Analysis of bound and unbound fractions by SDS-PAGE and silver staining showed that unlabeled proteins in the reticulocyte lysate failed to bind to the GST-FEM-2 matrix, demonstrating its selectivity for FEM-3 (not shown).

\section{FEM-2 exhibits protein phosphatase activity in vitro}

FEM-2 is similar in sequence to protein serine/threonine phosphatases of Type $2 \mathrm{C}$ (PP2C), exhibiting $30-35 \%$ sequence identity with other members of the family over a region spanning $\sim 260$ amino acids (Pilgrim et al. 1995). FEM-2 differs from most $\mathrm{PP} 2 \mathrm{C}$ in possessing an aminoterminal extension of 185 amino acids that is novel in sequence. Because the similarity between FEM-2 and the PP2C family suggests that protein phosphorylation might be involved in sex determination in C. elegans, we sought to determine whether FEM-2 possesses protein phosphatase activity.

The standard assay for PP2C activity uses ${ }^{32} \mathrm{P}$-labeled, phosphorylated casein as a substrate (McGowan and Cohen 1988). In the presence of magnesium, GST-FEM-2, but not GST, readily dephosphorylated ${ }^{32} \mathrm{P}$-casein (Fig. 4A). Magnesium dependence is one of the defining characteristics of Type $2 \mathrm{C}$ protein phosphatase activity $/ \mathrm{Co}$ hen 19891. Omission of magnesium from the reaction abolished the casein phosphatase activity of GST-FEM-2 (Fig. 4B), supporting the conclusion that FEM-2 is a Type $2 \mathrm{C}$ protein phosphatase.

A typical PP2C requires magnesium for substrate binding (McGowan and Cohen 1988). GST-FEM-2 retained FEM-3-binding activity in the absence of magnesium (Fig. 3), indicating that the interaction between FEM-2 and FEM-3 differs from a canonical PP2C-substrate interaction. FEM-3 may not be a substrate for FEM-2, but we cannot rule out the possibility that it is (see Discussion).

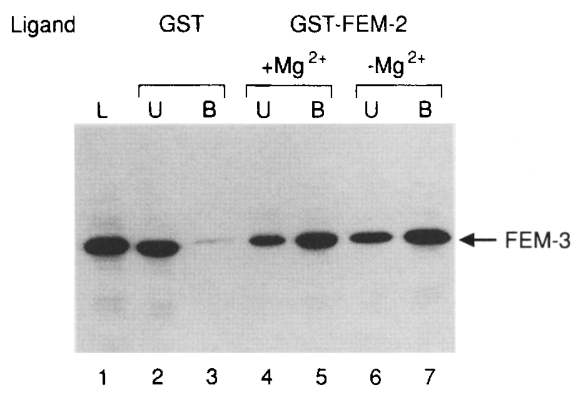

Figure 3. Interaction of ${ }^{35}$ S-labeled Myc-FEM-3 with GSTFEM-2-coated beads. Aliquots of an in vitro translation reaction containing ${ }^{35} \mathrm{~S}-\mathrm{Myc}-\mathrm{FEM}-3$ were incubated with beads coated either with GST $(10 \mathrm{mg} / \mathrm{ml})$ or with GST-FEM-2 $(5 \mathrm{mg} / \mathrm{ml})$. Binding reactions with GST-FEM-2 beads contained either 20 mM $\mathrm{MgCl}_{2}\left(+\mathrm{Mg}^{2+}\right.$, lanes 4,5) or $20 \mathrm{mM}$ EDTA $/-\mathrm{Mg}^{2+}$, lanes $6,7)$. The beads were collected and the supernatant reserved as the unbound fraction. After repeated washing of the beads, they were boiled to release bound proteins. Equal proportions of load $(\mathrm{L})$, unbound $(\mathrm{U})$, and bound $(\mathrm{B})$ fractions were analyzed by SDSPAGE and fluorography. 
A

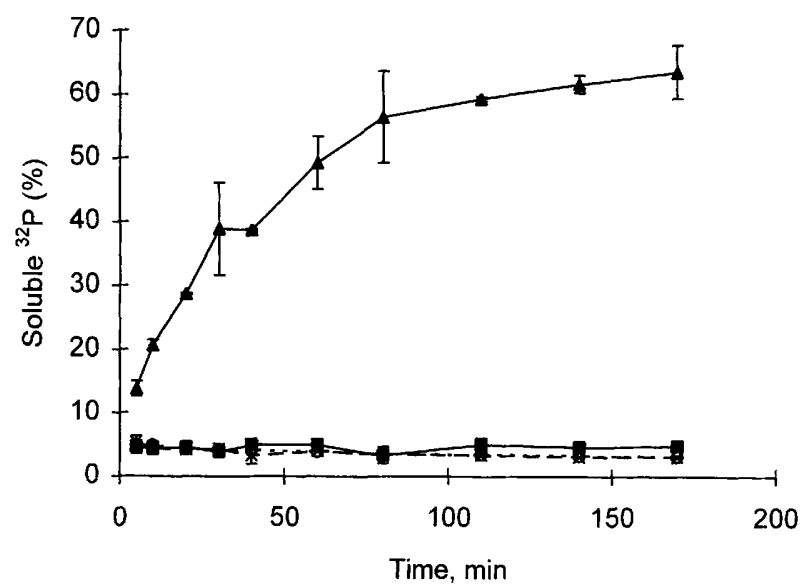

B

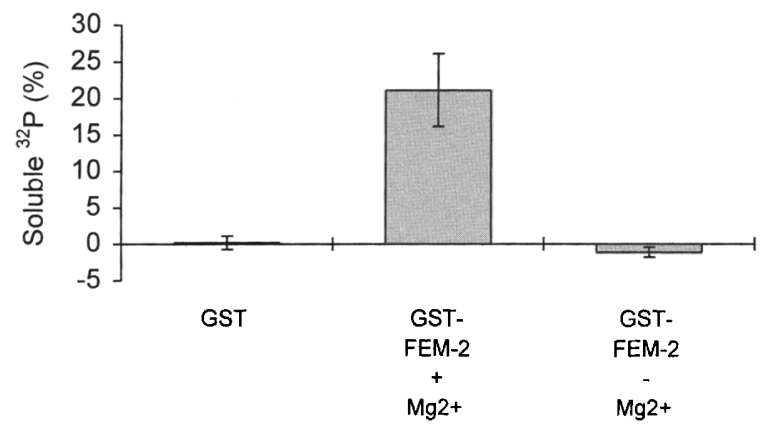

Figure 4. Casein phosphatase activity of FEM-2. (A) Time course of phosphate release from ${ }^{32} \mathrm{P}$-casein by GST $|\mathrm{O}|, \mathrm{GST}-$ FEM-2 $|+|(\mathbf{\Delta}), \quad$ GST-FEM-2(R336K) (D), and GST-FEM2 (R336A) ( $\times$ ). Assays were performed in triplicate with $2 \mu \mathrm{g}$ of GST fusion protein. Radioactivity released from the substrate at each sampling time is plotted as a percentage of the input radioactivity. (B) Magnesium-dependence of the phosphatase activity of FEM-2. Assays were performed in triplicate with $1 \mu \mathrm{g}$ of the indicated protein and either $20 \mathrm{mM} \mathrm{MgCl}_{2}$ or $20 \mathrm{mM}$ EDTA $\left(-\mathrm{Mg}^{2+}\right)$, and reactions were stopped after $15 \mathrm{~min}$. Soluble ${ }^{32} \mathrm{P}$ detected in the absence of added protein $(3-5 \%$ of the total) was subtracted from the total to give the values shown.

Mutations affecting the casein phosphatase activity of FEM-2

To test whether male development in C. elegans requires the phosphatase activity of FEM-2, we produced mutant forms of the protein that lacked phosphatase activity but retained FEM-3-binding activity. Sequence conservation within the PP2C family provides the only available guide to the sequence requirements for PP2C activity, because the structure of the PP2C catalytic domain and the identities of its catalytically important amino acid residues are unknown. PP2Cs are unrelated in sequence to protein phosphatases of other families
(Shenolikar 1994). Comparison of 14 PP2C sequences from yeasts, protists, plants, and mammals reveals 22 invariant amino acid residues, eight of which lie within the 30-amino-acid region shown in Figure 5. The temperature-sensitive, partial loss-of-function fem-2 allele, b245, carries a missense mutation that substitutes glutamate for the conserved glycine residue at position 339 (Pilgrim et al. 1995). The effects of the $b 245$ mutation on the phosphatase activity, folding, and stability of FEM-2 are not known, but because fem-2(b245) retains significant biological activity (Kimble et al. 1984), we chose to test the effects of mutations affecting a different conserved amino acid residue. We produced mutations causing the replacement of the invariant arginine residue at position 336 (R336) with either lysine (R336K) or alanine (R336A). These substitutions were intended to disrupt interactions involving the side chain of R336 but to have minimal steric or electrostatic effects on other interactions, so as to interfere minimally with the overall structure and stability of the protein /Cunningham and Wells 1989).

GST-FEM-2 fusion proteins carrying either the R336K or the R336A substitution were expressed as soluble proteins in Escherichia coli, suggesting that they were not severely misfolded. Both GST-FEM-2(R336K) and GSTFEM-2(R336A) exhibited FEM-3 binding activity similar to that of wild-type GST-FEM-2 in batch affinity chromatography experiments (Fig. 6), supporting the contention that neither mutation grossly perturbed the overall structure of FEM-2. Both mutations nevertheless abolished the casein phosphatase activity of FEM-2, as shown in Figure 4A.

\section{Effects of phosphatase-inactivating mutations on the masculinizing activity of FEM-2}

To assay the ability of wild-type and mutant fem-2 cDNAs to promote male development, we placed them under the control of a C. elegans heat-shock promoter and introduced them into nematodes carrying a chromosomal null allele of $f e m-2, e 2105$. Animals homozygous

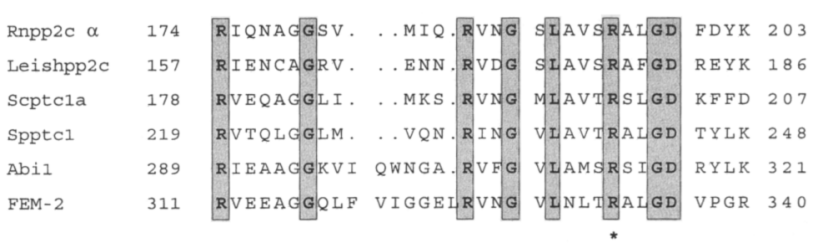

Figure 5. Sequence alignment of FEM-2 with representative PP2C family members in the vicinity of Arginine 336 (indicated with *. The sequence of FEM-2 predicted from cDNA clones isolated in this study agrees with that reported by Pilgrim et al. (1995; GenBank accession no. U29515). Other sequences and their data-base accession numbers are: Rnpp2c, rat PP2C $\alpha$ (J04503); Leishpp2c, Leishmania chagasi PP2C (L15559); Scptcla, Saccharomyces cerevisiae Ptcl (L14593); Spptcl, Schizosaccharomyces pombe ptc1 (L26970); Abil, Arabidopsis thaliana Abil (X78886). 


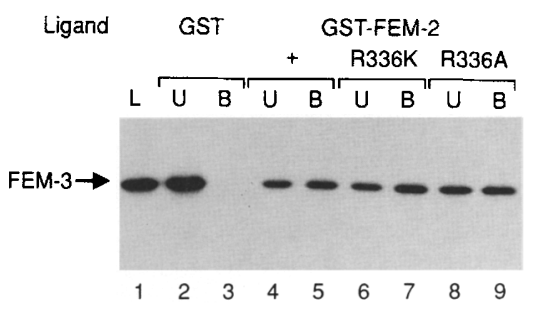

Figure 6. FEM-3-binding activity of FEM-2 variants lacking phosphatase activity. Beads coated with $3 \mathrm{mg} / \mathrm{ml}$ GST (lanes 2,3), $1.5 \mathrm{mg} / \mathrm{ml}$ GST-FEM-2(+) (lanes 4,5), GST-FEM-2(R336K) (lanes 6,7), or GST-FEM-2(R336A) (lanes 8,9) were tested for binding to ${ }^{35} \mathrm{~S}-\mathrm{Myc}-\mathrm{FEM}-3$ produced by in vitro translation. Equal proportions of the in vitro translation reaction ( $\mathrm{L}$, lane 1), the unbound ( $U$ ) and bound (B) fractions were analyzed by SDSPAGE and fluorography.

for fem-2(e2105), if descended from a homozygous fem-2 mother, develop as females at $25^{\circ} \mathrm{C}$ irrespective of their karyotype (Hodgkin 1986). We refer to these animals as fem-2 $\mathrm{m}-\mathrm{z}-$ (following the convention of Hodgkin 1986 ) to indicate that they lack both maternal and zygotic fem-2 activity. We produced $f e m-2 \mathrm{~m}-\mathrm{z}-\mathrm{mu}-$ tants carrying wild-type or mutant heat shock-fem-2 (hs-fem-2) transgenes on extrachromosomal arrays. We then subjected them to heat shocks at intervals of $18 \mathrm{hr}$ throughout development and determined the extent to which transgene expression rescued male development. To allow assessment of masculinizing activity in both $\mathrm{XX}$ and XO fem-2 $\mathrm{m}-\mathrm{z}-$ animals, we used a strain homozygous for the him-5(e1490) mutation, which causes hermaphrodites to produce about $30 \%$ XO self-progeny (Hodgkin et al. 1979).

Heat shock-induced synthesis of amino-terminally Myc-tagged FEM-2 (HS-Myc-FEM-2) caused masculinization in $30 \%$ of transgenic fem-2 $\mathrm{m}-\mathrm{z}-$; him-5 mu- tant animals (Table 2). We observed extensive masculinization of the somatic gonad, ventral hypodermis, and the tail structures (Table 2; Fig. 7). Rescue of spermatogenesis was very infrequent, probably because the transgene was expressed poorly in the germ line. Several groups have reported previously that germ-line expression of transgenes controlled by the heat shock promoter is weak or undetectable (Stringham et al. 1992; Roehl and Kimble 1993; Kuwabara and Kimble 1995; Browning and Strome 1996). Because the fraction of transgenic animals exhibiting somatic masculinization corresponded closely to the fraction of XO animals produced by him5(e1490) homozygotes, we conclude that transgene expression allowed at least partial rescue of male development in the majority of XO fem-2 $\mathrm{m}-\mathrm{z}-$ individuals. The inference that all of the masculinized fem-2; him-5 animals were of XO karyotype is supported by the observation that HS-Myc-FEM-2|+| did not cause inappropriate somatic masculinization of $\mathrm{XX}$ animals even when they were chromosomally fem-2(+) (Table 2).

Phosphatase-inactivating substitutions of arginine 336 compromised the rescuing activity of HS-Myc-FEM-2 severely. The alanine mutant, HS-Myc-FEM-2(R336A), was almost completely ineffectual at rescuing male development in fem-2 m-z-; him-5 mutants. The only apparent sign of masculinization among 166 mutant animals expressing HS-Myc-FEM-2(R336A) was the presence, in the tails of two animals, of small refractile deposits that may have resulted from abortive spicule development (Table 2). Replacement of arginine 336 by lysine also impaired fem-2 function, although somewhat less dramatically. HS-Myc-FEM-2(R336K) caused observable masculinization in only $7 \%$ of the transgenic fem-2 m-z-; him-5 mutants examined after repeated heat shock, corresponding to about $1 / 4$ of the expected number of XO animals in the sample. Among the few animals masculinized by HS-Myc-FEM-2(R336K), the

Table 2. Effect of phosphatase-inactivating mutations on the masculinizing activity of FEM-2

\begin{tabular}{|c|c|c|c|c|c|c|c|c|c|c|}
\hline \multirow[b]{2}{*}{$\begin{array}{l}\text { fem-2 } \\
\text { genotype }\end{array}$} & \multirow[b]{2}{*}{ Karyotype $^{a}$} & \multirow[b]{2}{*}{$\begin{array}{l}\text { HS-FEM-2 } \\
\text { variant }\end{array}$} & \multirow[b]{2}{*}{$\begin{array}{l}\text { Heat } \\
\text { shock }\end{array}$} & \multirow[b]{2}{*}{$\begin{array}{l}\% \\
\text { masculinized } \\
\text { rollers }^{b}(\mathrm{n})\end{array}$} & \multicolumn{6}{|c|}{$\begin{array}{l}\text { Tissues exhibiting masculinization } \\
\text { (number with indicated masculinized feature/ } \\
\text { number of masculinized animals examined } \text { ) }\end{array}$} \\
\hline & & & & & $\begin{array}{l}\text { vulva or } \\
\text { absent or } \\
\text { defective }\end{array}$ & $\begin{array}{l}\text { somatic } \\
\text { gonad }\end{array}$ & fan & $\begin{array}{l}\text { tail } \\
\text { rays }\end{array}$ & $\begin{array}{l}\text { spicule } \\
\text { material }\end{array}$ & sperm \\
\hline+ & $\mathrm{XX}$ & Myc-FEM-21+1 & + & $0\langle 81\rangle$ & & & & & & \\
\hline$e 2105$ & $\mathrm{Xx}+\mathrm{xO}$ & Myc-FEM-2i+1 & + & $30(253)$ & $39 / 47$ & $31 / 47$ & $46 / 47$ & $38 / 47$ & $47 / 47$ & $1 / 47$ \\
\hline & & & - & $8\{381\}$ & $16 / 31$ & $8 / 31$ & $18 / 31$ & $16 / 31$ & $30 / 31$ & $0 / 31$ \\
\hline$e 2105$ & $\mathrm{XX}+\mathrm{XO}$ & Myc-FEM-2(R336K) & + & $7(201)$ & $5 / 15$ & $5 / 15$ & $8 / 15$ & $3 / 15$ & $10 / 15$ & $0 / 15$ \\
\hline & & & - & $2(327)$ & $0 / 6$ & $0 / 6$ & $0 / 6$ & $1 / 6$ & $6 / 6$ & $0 / 6$ \\
\hline$e 2105$ & $\mathrm{XX}+\mathrm{XO}$ & Myc-FEM-2(R336A) & $\begin{array}{l}+ \\
-\end{array}$ & $\begin{array}{l}1(166) \\
0(337)\end{array}$ & $0 / 2$ & $0 / 2$ & $0 / 2$ & $0 / 2$ & $2 / 2$ & $0 / 2$ \\
\hline
\end{tabular}

${ }^{a}$ Transgenic lines carrying fem-2(e2105) also carried him-5(el490), which caused the production of about $30 \%$ XO animals.

${ }^{\mathrm{b}}$ The total number of masculinized animals was scored using a dissecting microscope (40× magnification). The total number of transgenic animals examined is given in parentheses.

${ }^{c}$ Animals exhibiting masculinization visible in the dissecting microscope were examined using Nomarski microscopy $(400 \times$ magnification/ to assess the masculinization of various tissues. All masculinized animals expressing mutant forms of Myc-FEM-2 and over half of the animals that were masculinized by expression of Myc-FEM-2 $|+|$ were examined in this way. 

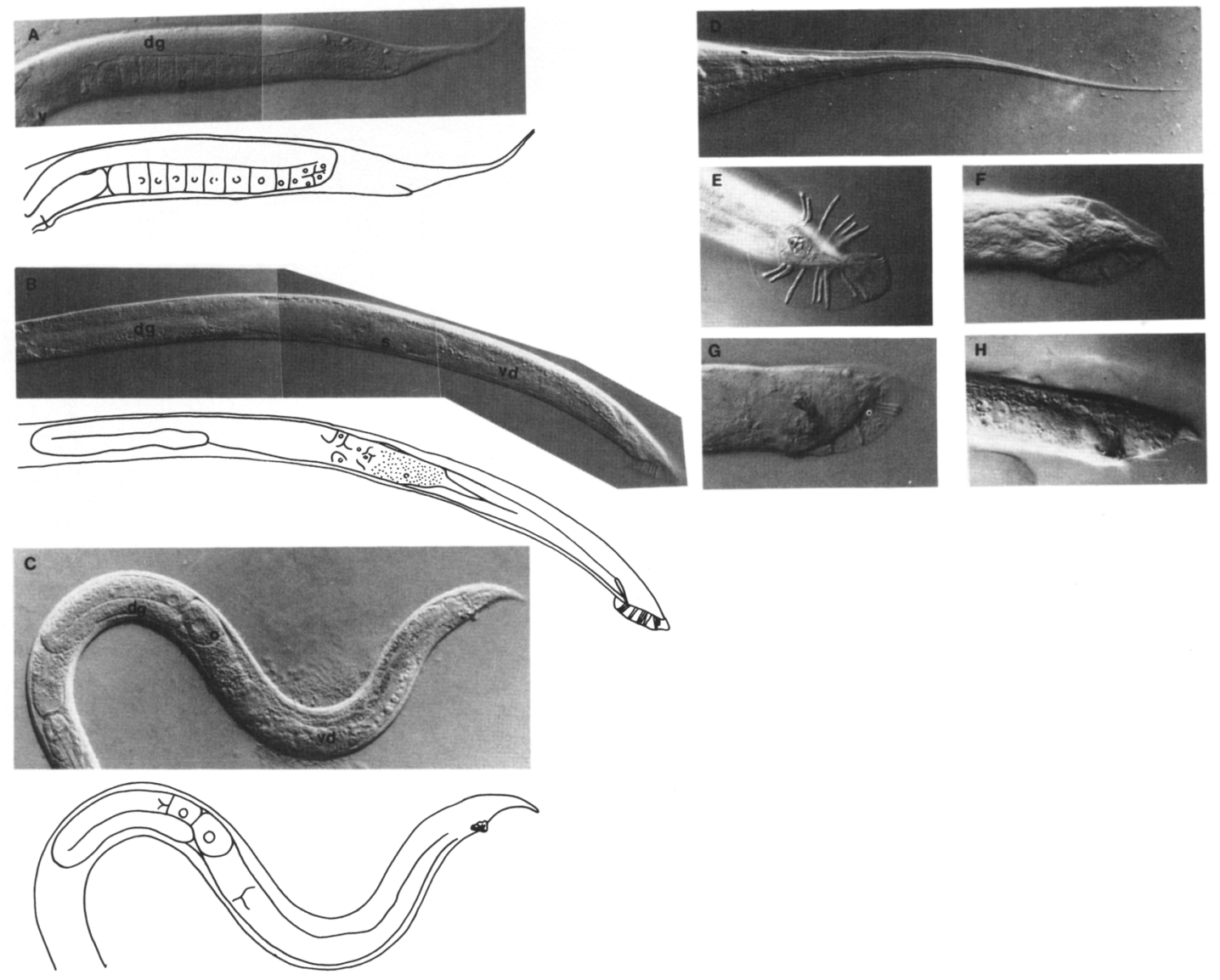

Figure 7. Rescue of male development by heat-shock expression of Myc-FEM-2. $(A-C)$ Nomarski photomicrographs and tracings showing gonad morphology: $(A)$ fem $-2 \mathrm{~m}-\mathrm{z}-$ female, raised at $25^{\circ} \mathrm{C}(\mathrm{XX}$ or XO), showing only the posterior gonad arm; $(B)$ wild-type $\mathrm{XO}$ male; $(C)$ fem-2 $\mathrm{m}-\mathrm{z}-\mathrm{XO}$ intersex expressing HS-FEM-2(+), with rescued male gonad morphology. (dg) distal gonad arm (dorsal in female gonad in $A$, and ventral in male gonads in $B$ and $C)_{i}(\mathrm{v})$ vulva ${ }_{i}(\mathrm{vd})$ vas deferens; $(\mathrm{o})$ oocyte; $(\mathrm{s})$ sperm. $(D-H)$ Nomarski photomicrographs showing tail morphology. (D) fem-2 $\mathrm{m}-\mathrm{z}-$ female, raised at $25^{\circ} \mathrm{C}$ (XX or XO); (E) wild-type XO male; $(F-H)$ fem-2 $\mathrm{m}-\mathrm{z}-\mathrm{XO}$ animals expressing HS-FEM $-2|+|$, showing variation in the extent of rescue of male tail development. Heat-shock expression of FEM-2(+) usually caused partial rescue of the tail fan, rays, and spicules, as in $F$ and $G$. Expression of FEM-2(R336K) caused weaker and less frequent rescue of male tail development. Masculinized animals expressing FEM-2/R336K/generally exhibited masculinization similar to or weaker than the animal shown in $H$. Expression of FEM-2(R336A) rarely caused any detectable masculinization, as detailed in Table 2 and in the text.

average extent of male development was significantly lower than in mutants rescued by HS-Myc-FEM- $21+1$ (Table 2). HS-Myc-FEM-2(+) and both the R336K and R336A mutants accumulated to similar levels in nematodes following a single heat shock, arguing that the difference in their masculinizing activities did not result from differences in synthesis or stability (Fig. 8). Instead, we conclude that the protein phosphatase activity of FEM-2 is important for its normal role in promoting male development, and that the R336A and R336K substitutions impair the masculinizing activity of FEM-2 as a direct consequence of their effects on its phosphatase activity. Our results imply that signaling through the sex determination pathway in C. elegans involves the regulation of protein phosphorylation.

\section{Discussion}

The FEM proteins transduce an extracellular, masculin- izing signal to bring about the negative regulation of TRA-1 in somatic tissues and the activation of other functions that are required for spermatogenesis. We have demonstrated a specific interaction between two of the FEM proteins, FEM-3 and FEM-2. We have shown that purified, bacterially expressed GST-FEM-2 exhibits magnesium-dependent casein phosphatase activity typical of PP2C, and we have provided evidence that the phosphatase activity of FEM-2 is required for male development.

\section{Significance of the interaction between FEM-3 and FEM-2}

Genetic analysis of fem-2 and fem-3 established that both are required for male development and that both act at the same level in the genetic cascade controlling sex determination (Hodgkin 1986). On the basis of their ability to associate in the yeast two-hybrid system and in 


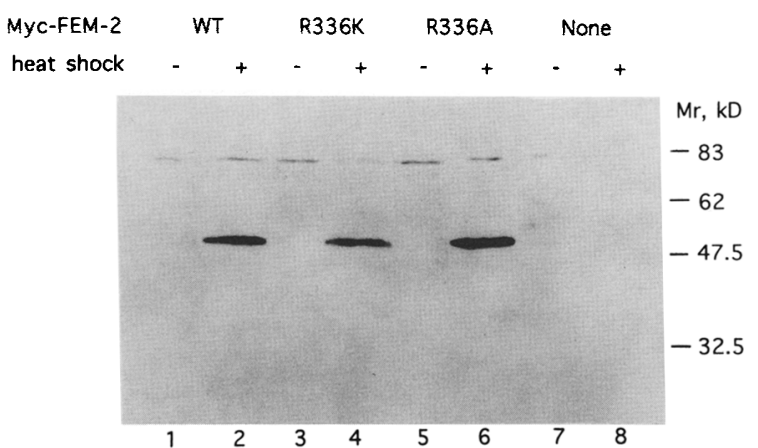

Figure 8. Expression of wild-type and mutant Myc-FEM-2 in transgenic nematodes. Lysates prepared from animals maintained continuously at $25^{\circ} \mathrm{C} \mid-$ heat shock; lanes $\left.1,3,5,7\right)$, and from animals subjected to a 2-hr heat shock and a 2-hr recovery period at $25^{\circ} \mathrm{C}(+$ heat shock, lanes $2,4,6,8)$, were analyzed by SDS-PAGE and immunoblotting with monoclonal antibody 9E10. Lysates were from transgenic nematodes carrying plasmids encoding Myc-FEM-2(+ ) (lanes 1,2), Myc-FEM-2(R336K) (lanes 3,4), or Myc-FEM-2(R336A) (lanes 5,6), or from nontransgenic him-5 nematodes (lanes 7,8). Each Myc-FEM-2 variant $(\sim 55 \mathrm{kD} \mathrm{Mr})$ accumulates to similar levels following heat shock.

vitro, we suggest that FEM-2 and FEM-3 interact directly in C. elegans to promote male development. Understanding the functional consequences of the interaction between FEM-2 and FEM-3 will require further analysis, but here we consider three models. In the first, FEM-3 regulates FEM-2 positively. FEM-3 binding is clearly not required in vitro for the phosphatase activity of FEM-2, but it may serve to target specific substrates for dephosphorylation in vivo. It could do so by localizing FEM-2 to a particular subcellular compartment or by increasing the affinity or specific activity of FEM-2 toward its substrates. In this case the role of FEM-3 would be analogous to the roles of the targeting subunits of Type 1 protein serine/threonine phosphatases (PP1) or the regulatory subunits of PP2A (Cohen 1989; Shenolikar 1994). Although canonical PP2C enzymes exist as monomers /Cohen 1989|, FEM-2 is one of several members of the PP2C family that contain, in addition to the catalytic domain, an amino-terminal domain that might mediate associations with regulators (Leung et al. 1994; Meyer et al. 1994; Stone et al. 1994; Pilgrim et al. 1995).

A second possibility is that FEM-2 dephosphorylates FEM-3, activating it for binding to other target proteins. The interaction between FEM-2 and FEM-3 differs from other PP2C-substrate interactions (McGowan and Cohen 1988) in that it is magnesium independent. However, as FEM-2 has a specific developmental role, it might have a unique substrate recognition domain, perhaps involving its unique amino-terminal extension (Pilgrim et al. 1995). Because TRA-2A is the principal negative regulator of the FEM proteins (Kuwabara and Kimble 1995|, FEM-3 phosphorylation, if it occurs, must be either TRA-2A-dependent or else insufficient to inhibit FEM activity in the absence of TRA-2A. TRA-2A does not resemble a kinase in sequence (Kuwabara et al.
1992), but it could recruit a kinase to FEM-3. A model in which FEM-2 activates FEM-3 by dephosphorylation, although subject to several constraints, cannot be excluded presently.

Finally, interaction between FEM-2 and FEM-3 need not alter the activity of either participant but may serve instead to facilitate their cooperation in regulating common targets. For example, dephosphorylation of a target protein by FEM-2 may allow FEM-3 to bind and regulate the activity of that target.

Rescue of the fem-2 mutant phenotype by a heat-shock promoter-driven $c D N A$

Extrachromosomal arrays expressing Myc-FEM-2 $1+1$ under the control of a C. elegans heat-shock promoter (Stringham et al. 1992; Mello and Fire 1995) allowed extensive rescue of $X \mathrm{O}$ male somatic development. However, we seldom observed complete somatic rescue. We obtained identical results with an untagged HS-FEM$2|+|$ transgene, establishing that the Myc epitope tag did not interfere with FEM-2 function (our study, unpubl.). Mitotic loss of the transgene, resulting in genetic mosaicism (Stinchcomb et al. 1985), may have limited the extent of rescue. In addition, pulsed expression of the transgene at regular intervals may not have provided adequate levels of FEM-2 at the correct times in all sexually dimorphic tissues.

\section{Requirement for FEM-2 protein phosphatase activity in male development}

Substitution of arginine 336 of FEM-2, a residue that is invariant within the PP2C family, with either lysine or alanine inactivates FEM-2 as a casein phosphatase and impairs dramatically its ability to rescue male development in fem-2 m-z $-X O$ mutants. Because the mutant proteins are expressed stably in transgenic nematodes, and because they retain FEM-3-binding activity similar to wild-type FEM-2 in vitro, we attribute the defect in their masculinizing activity primarily to their inactivity as protein phosphatases. FEM-2(R336K) and FEM2(R336A) are not, however, equivalent with respect to their ability to promote male development. Although both mutant proteins lack detectable casein phosphatase activity, FEM-2(R336K) retains significantly more residual masculinizing activity than FEM-2(R336A), which is essentially inactive. It may be that FEM-2(R336K) retains significant phosphatase activity in vivo against its natural substrate, whereas FEM-2(R336A) does not. However, it is also possible that a phosphatase-independent mechanism can cause incomplete male development.

Genetic evidence suggests that limited male development can occur in the absence of fem-2 function: The nonsense mutation $e 2105$, which truncates the fem-2 open reading frame near the beginning of the phosphatase domain (Pilgrim et al. 1995), causes only partial feminization of $X \mathrm{O}$ fem-2 $\mathrm{m}-\mathrm{z}-$ mutants at $15^{\circ} \mathrm{C}$ (Hodgkin 1986). The temperature sensitivity of fem- 
2(e2105) is susceptible to two types of explanation: the first is that another protein phosphatase is able to substitute for FEM-2 at low temperature. This possibility should not be discounted, as partial or complete functional redundancy among protein phosphatases in signal transduction is not uncommon (Maeda et al. 1993; Hunter 1995; Shiozaki and Russell 1995). The second possibility is that FEM-1 and FEM- 3 can bring about incomplete male development at $15^{\circ} \mathrm{C}$ by a phosphataseindependent mechanism. FEM-2 (R336K), even if it lacks phosphatase activity utterly, might potentiate a phosphatase-independent regulatory activity of FEM-1 and FEM-3. For example, FEM-2(R336K) might mediate the formation of a complex involving FEM-3, FEM-1, and TRA-1, resulting in partial inhibition of TRA-1 even at $25^{\circ} \mathrm{C}$, the incubation temperature in our experiments. This type of model would oblige us to suppose that FEM2(R336A) is less effective than FEM-2(R336K) at stimulating the other FEM proteins because of a defect in an as-yet-unidentified interaction.

\section{Candidate targets for the FEM-2 phosphatase}

A requirement for the phosphatase activity of FEM-2 in sex determination, even if it is not an absolute requirement, implies that FEM-2 promotes male development by antagonizing the feminizing activity of a protein $\mathrm{ki}$ nase. The identity of this kinase and the substrate that it shares with FEM-2 remain to be determined. Either of the other FEM proteins might be regulated negatively by phosphorylation. We have already discussed a model in which FEM-2 activates FEM-3 by dephosphorylation. An analogous model that invokes dephosphorylation as a mechanism for activating FEM-1 is subject to the same constraints.

TRA-1 proteins, as the principal targets of fem activity in somatic tissues, are candidate substrates for FEM-2mediated dephosphorylation. Gain-of-function mutations in tra-1 render its activity insensitive to regulation by the FEM proteins (Hodgkin 1987). Most are missense mutations that affect a small amino-terminal region common to TRA-1A and TRA-1B, referred to as the GF region (De Bono et al. 1995). Two tra-1 splicing mutations that cause deletion of the GF region also have gainof-function properties (De Bono et al. 1995). The GF region may be a target for a negative regulator, perhaps one of the FEM proteins. Models in which FEM-2 regulates TRA-1 by dephosphorylation in a manner sensitive to the GF region could take several forms. The GF region may constitute an intrinsically inhibitory domain of TRA-1, and phosphorylation of this domain might prevent it from exercising an inhibitory influence, perhaps by locking TRA-1 in an active conformation. In this case, dephosphorylation by FEM-2 would allow the GF region to reassert its inhibitory activity. Alternatively, phosphorylation at a site outside the GF region might be necessary for TRA-1 activation, but FEM-2-mediated dephosphorylation might require recognition of the GF region by FEM- 2 itself or the other FEM proteins. In either of these models, mutations that alter or delete the GF region could have the effect of preventing dephosphorylation and inactivation of TRA-1. A third possibility is that dephosphorylation of the GF region by FEM-2 may be a prerequisite for the binding of another negative regulator, perhaps another FEM protein, to that region.

The FEM proteins have targets other than TRA-1 in the germ-line (Doniach and Hodgkin 1984; Hodgkin 1986), any of which might also be a substrate for FEM-2. Candidates include the products of the genes fog-1 and fog-3 (Barton and Kimble 1990; Ellis and Kimble 1995), which have not been characterized molecularly.

\section{Conclusion and future directions}

Our results demonstrate that regulation of protein phosphorylation plays an important role in signal transduction through the sex-determining pathway in C. elegans. Enzymes of the PP2C family have been implicated previously in signal transduction pathways controlling osmoregulation in yeast (Maeda et al. 1994; Shiozaki and Russell 1995) and responses to abscisic acid in Arabidopsis (Leung et al. 1994; Meyer et al. 1994), but FEM-2 is the first example of a Type $2 \mathrm{C}$ protein serine/threonine phosphatase that is required specifically for the regulation of development in a metazoan. Progress in understanding the role of phosphorylation in sex determination will require identification of the endogenous substrates of FEM-2 and an analysis of the effects of FEM-3 binding on the subcellular distribution and specificity of FEM-2. At least one class of gene involved in sex determination likely awaits identification: at least one gene must encode a kinase that phosphorylates the substrate of FEM-2. Such a kinase is presumably necessary for the adoption of female cell fates, although its role need not be restricted to the regulation of sex determination. The sex-determining pathway in C. elegans may provide an example of a signal transduction pathway in which the regulation of protein phosphatase activity, rather than the activity of the opposing protein kinases, is paramount in determining the output of the pathway.

\section{Materials and methods}

C. elegans strains and culture

Methods for the culture and genetic manipulation of C. elegans were those described by Sulston and Hodgkin (1988), except that we used MYOB agar (Church et al. 1995) in place of NGM. We used the standard wild-type strain of $C$. elegans var. Bristol, N2, (Brenner 1974). Strain AS204, a derivative of N2, is of genotype fem-2(e2105)/unc-45(r450) dpy-1(e1) III; him-5(e1490) V. [fem2(e2105) (Hodgkin 1986) is a nonsense allele that is likely to be null (Pilgrim et al. 1995). him-5 (e1490) (Hodgkin et al. 1979) causes homozygous hermaphrodites to produce about $30 \%$ XO self-progeny as a result of $\mathrm{X}$ chromosome nondisjunction. The unc-45(r450) and dpy-1(e1) marker mutations are described in Hodgkin (1988).]

\section{Yeast two-hybrid screen}

Yeast were grown on standard complete and selective media as appropriate. (Sherman 1991). Yeast transformation was per- 
formed using the LiAc/single-stranded carrier DNA/PEG method (Schiestl and Gietz 1989).

We carried out a two-hybrid screen using the system described by Durfee et al. (1993). Dr. R. Barstead (Oklahoma Medical Research Foundation) generously provided a C. elegans cDNA library in $\lambda A C T$. The Cre-expressing $E$. coli strain RB4E (R. Barstead, pers. comm.), a derivative of BNN132 (Elledge et al. 1991), was used for conversion of $\lambda$ ACT clones to plasmids. Yeast strain Y153 was transformed to tryptophan prototrophy with plasmid AS\#1197, a pAS1 derivative that directs the expression of FEM-3 fused to the DNA-binding domain of GAL4 (GAL4DB-FEM-3). The resulting strain was transformed with library plasmid DNA, and $\operatorname{Trp}^{+}, \mathrm{Leu}^{+}, \mathrm{His}^{+}, \mathrm{lacZ}{ }^{+}$transformants were identified as described by Durfee et al. (1993). Library plasmids were recovered from these transformants, and the recovered plasmids were retested for interaction with GAL4DB-FEM-3 in Y153. Those that were positive upon retesting were introduced into Y153 alone or with pSE1112, which encodes a GAL4DB-SNF1 fusion (Durfee et al. 1993) that served as a negative control. Three plasmids that activated reporter gene expression only in the presence of GAL4DB-FEM-3 were retained for further analysis. $\beta$-galactosidase activity in liquid cultures was assayed as described (Ausubel et al. 1989). Three or more independent transformants of each type were assayed. Values were normalized to the level of activity resulting from coexpression of the FEM-3 DNA-binding domain fusion and a SNF4 activation domain fusion (Durfee et al. 1993).

DNA sequencing (Sanger et al. 1977) revealed that two of the three plasmids recovered in the two-hybrid screen carried fem-2 cDNA inserts. Both fem-2 cDNAs included the complete fem-2 coding sequence and $5^{\prime}$ untranslated region (which does not contain any in-frame stop codons), but they differed in the extent of the $3^{\prime}$ untranslated sequence they contained. The fem-2 cDNA carried by plasmid AS\# 1245 was used for further experiments.

\section{Coimmunoprecipitations}

The cDNA insert from plasmid AS\#1245 was subcloned in plasmid T7ßSal (Norman et al. 1988) to produce plasmid AS\# 1285. Transcription of AS\#1285 with T7 RNA polymerase produces an mRNA encoding FEM-2 with an amino-terminal extension of 24 amino acid residues. Plasmid AS\#1184 consists of a fem-3 cDNA in a derivative of T7plink that carries the sequence encoding the 9E10 Myc epitope tag (Dalton and Treisman 1992; Bardwell and Treisman 1994). Transcription of AS\#1184 with T7 RNA polymerase produces an mRNA that encodes aminoterminally Myc epitope-tagged FEM-3.

Plasmids AS\# 1184 and AS\#1285 were transcribed and translated in the presence of $\left[{ }^{32} \mathrm{~S}\right]$ methionine using the T7 TNT system (Promega). A $5 \mu \mathrm{l}$ aliquot of a translation reaction containing either $\left[{ }^{35} \mathrm{~S} \mid-\mathrm{FEM}-2,\left[{ }^{35} \mathrm{~S}\right]-\mathrm{FEM}-3\right.$, or both, was diluted to 100 $\mu l$ with Buffer A [ $10 \%$ glycerol, $20 \mathrm{~mm}$ HEPES (pH 7.9), $50 \mathrm{~mm}$ ammonium sulfate, $1 \mathrm{mM}$ DTT, $1 \%$ Triton X-100, 0.1\% SDS, $175 \mu \mathrm{g} / \mathrm{ml} \mathrm{PMSF}$, and $10 \mu \mathrm{g} / \mathrm{ml}$ each of aprotinin, leupeptin, and pepstatin; Kolodziej and Young 1991]. Subsequent steps were carried out at $4^{\circ} \mathrm{C}$. The solution was mixed with $5 \mu$ l of Protein A Sepharose CL-4B (Pharmacia) in Buffer A $(100 \mathrm{mg} / \mathrm{ml})$ for $30 \mathrm{~min}$ and centrifuged at $5000 \mathrm{rpm}$ for $30 \mathrm{sec}$. A cell culture supernatant containing monoclonal antibody 9E10 $4 \mu \mathrm{l})$ (Evan et al. 1985/ was added to the supernatant and mixed for $\mathrm{l} \mathrm{hr}$. Protein A-Sepharose (25 $\mu \mathrm{l}$ of a $100 \mathrm{mg} / \mathrm{ml}$ suspension) was added and mixed for $1 \mathrm{hr}$ before being collected by centrifugation as above. The immunoprecipitates were washed twice in RIPA-500 buffer [50 mm Tris- $\mathrm{HCl}(\mathrm{pH} 8), 500 \mathrm{~mm} \mathrm{NaCl}, 0.1 \%$ SDS, $0.5 \% \mathrm{Na}$ deoxycholate, and $1 \%$ Triton $\mathrm{X}-100]$, and once in
Buffer A. They were resuspended in SDS sample buffer, boiled, centrifuged briefly, and samples of the supernatants were analyzed on $10 \%$ SDS-polyacrylamide gels. Gels were fixed, treated with Amplify (Amersham) and exposed to X-ray film at $-70^{\circ} \mathrm{C}$.

\section{Preparation of GST-FEM-2}

The fem-2 cDNA insert of plasmid AS\# 1245 was subcloned in pGEX-4T2 (Pharmacia) to produce AS\#1252, which encodes GST-FEM-2. Synthesis of GST-FEM-2 was induced with 0.1 mM IPTG in E. coli DH5 cells carrying AS\#1252. Cells were harvested by centrifugation, resuspended in PBST [150 mM $\mathrm{NaCl}, 3 \mathrm{~mm} \mathrm{KCl}, 12 \mathrm{~mm} \mathrm{Na}$ phosphate (pH 7.2), and $1 \%$ Triton $\mathrm{X}-100]$ and lysed by sonication. The lysate was centrifuged to remove debris, and the supernatant was incubated with glutathione-Sepharose beads (Pharmacia). The beads were collected by centrifugation and washed three times with PBS. GSTFEM-2 was eluted with $25 \mathrm{~mm}$ glutathione in $50 \mathrm{~mm}$ Tris- $\mathrm{HCl}$, $\mathrm{pH}$ 8.0. After dialysis, the concentration of GST-FEM-2 was estimated by Bradford assay (Bio-Rad). Samples were subjected to SDS-PAGE and Coomassie staining to verify that full-length GST-FEM-2 was the predominant species.

Plasmids encoding GST-FEM-2(R336K or R336A) fusion proteins were produced in two steps: the pGEX-fem-2 plasmid AS\# 1252 was digested with HindIII and recircularized to delete the 500 bp HindIII fragment of fem-2 cDNA, and the corresponding HindIII fragment carrying the appropriate mutation was subcloned in the resulting plasmid.

\section{Phosphatase assay}

Casein was phosphorylated with $\left[\gamma^{-32} \mathrm{P}\right] \mathrm{ATP}$ and protein kinase A, purified over Sephadex G-50, and used as a substrate to assay the phosphatase activity of GST-FEM-2, using the methods described by McGowan and Cohen (1988). Assays were performed in triplicate using 1-2 $\mu$ g of GST or GST-FEM-2 in a reaction volume of $50-200 \mu \mathrm{l}$. Reactions contained $20 \mathrm{mM} \mathrm{MgCl}_{2}$ or 20 mM EDTA $\left(-\mathrm{Mg}^{2+}\right.$ in Figs. 3 and 4$)$.

\section{Batch affinity chromatography}

Aliquots $(25 \mu \mathrm{l})$ of glutathione-Sepharose beads carrying either GST or GST-FEM-2 were suspended in $100 \mu$ l of PBS containing $1 \%$ Triton X-100, $175 \mu \mathrm{g} / \mathrm{ml}$ PMSF, and $10 \mu \mathrm{g} / \mathrm{ml}$ each of pepstatin, leupeptin, and aprotinin. In initial experiments, GSTFEM-2 was bound to the beads at a concentration of $5 \mathrm{mg} / \mathrm{ml}$, GST at $10 \mathrm{mg} / \mathrm{ml}$. A $5-\mu \mathrm{l}$ aliquot of an in vitro translation reaction containing ${ }^{35}$ S-labeled Myc-FEM-3 (load) was added to the suspension. After incubation at room temperature for $1.5 \mathrm{hr}$, the beads were collected by centrifugation, and the supernatant was saved as the unbound fraction. The beads were washed 4 times with RIPA-500 before being boiled in SDS sample buffer to release bound proteins. Equal proportions of load, unbound, and bound fractions were analyzed by SDS-PAGE and fluorography, as described above.

Tests of whether the R336K or R336A mutations affected FEM-3 binding to GST-FEM-2 were performed with all GSTFEM-2 proteins at a concentration of $1.5 \mathrm{mg} / \mathrm{ml}$.

\section{Mutagenesis of codon 336 of fem-2}

A 500-bp HindIII fragment of fem-2 cDNA subcloned in pBluescriptII (Stratagene) was mutagenized with the degenerate oligonucleotide oAS150 [5'-CTAAATCTCACC(A or G)(A or C)AGCACTCGGAG-3'] using the method of Kunkel et al. (1987). 
Clones carrying mutations encoding R336K and R336A amino acid substitutions were identified by DNA sequencing. Mutant clones used for construction of expression plasmids were sequenced in their entirety.

\section{Construction of plasmids for heat shock-induced expression} of FEM-2 and Myc-FEM-2

The fem-2 cDNA in plasmid AS\#1245 was cloned in pPD49.83 (Mello and Fire 1995) to produce AS\#1255, which directs the expression of wild-type FEM-2 under the control of the hsp1641 promoter.

A 640 -bp XhoI-BamHI fragment of AS\#1245 was subcloned in pBluescriptII $(\mathrm{KS})+$. It was amplified by PCR using primers oAS157 (5'-GTGTGGTACCATGGCGGCCGCGAAAAAGTAAACGAGGAGC-3') and FPl (5'-GTAAAACGACGGCCAGT-3') to introduce an NcoI site at the start codon of fem-2 and a NotI site immediately downstream. The amplification product was subcloned in pBluescriptII $(\mathrm{SK})+$ as a KpnI-BamHI fragment. A cassette composed of annealed oligonucleotides oAS153 15'-GGCCGAACAGAAGCTTATC-TCTGAGGAAGATCTG-3') and oAS154 (5'-GGCCCAGATCTTCCTCAGAGATAAGCT-TCTGTTC-3'), encoding the 9E10 Myc epitope, was then inserted into the newly introduced NotI site in fem-2. [The NotI site in the pBSII(SK) + polylinker was first eliminated.] The entire insert was sequenced. A three-way ligation involving the 300-bp NcoI-Sall fragment of this plasmid, a 1.4-kb SalI-SmaI fragment of AS\#1255, carrying the remainder of fem-2 cDNA, and the 3.8-kb NcoI-EcoRV fragment of pPD49.83 (Mello and Fire 1995) produced plasmid AS\#1315. The hsp16-41 promoter in AS\#1315 directs the expression of a mRNA encoding full-length FEM-2 bearing an amino-terminal Myc tag. Homologous plasmids directing the synthesis of FEM2(R336K) and FEM-2(R336A) were constructed in the same way, except that the 1.4-kb SalI-SmaI fragment in each case was from a fem-2 plasmid carrying the relevant mutation.

\section{Heat shock rescue experiments}

Nematode transformation was carried out using the methods described by Mello and Fire (1995). Hermaphrodites of either strain N2 or AS204 were injected with a DNA mixture containing $50 \mu \mathrm{g} / \mathrm{ml}$ of plasmid pRF4, which carries the transformation marker rol-6(su1006 dm) (Mello et al. 1991), $20 \mu \mathrm{g} / \mathrm{ml}$ of the heat shock-fem-2 plasmid being tested, and $30 \mu \mathrm{g} / \mathrm{ml}$ of pBluescript to bring the total DNA concentration to $100 \mu \mathrm{g} / \mathrm{ml}$. Transgenic lines carrying the injected DNA on extrachromosomal arrays were established from F2 Rol progeny of injected animals.

Lines derived from AS204 were used to test the ability of each heat shock-fem-2 construct to rescue fem-2(e2105). Each plasmid was tested in at least three independent transgenic lines. Single Rol, non-Dpy, non-Unc XX animals were picked as L4 larvae to separate plates at $25^{\circ} \mathrm{C}$. As fem-2 exhibits maternal rescue (Hodgkin 1986), those animals that matured into selffertile hermaphrodites were of two classes: one-third were fem2(e2105) homozygotes, whereas the remaining two-thirds were heterozygous. Each Roller hermaphrodite was transferred to a new plate every 12-24 hr. Embryos deposited on one plate were allowed to develop at $25^{\circ} \mathrm{C}$ to determine the genotype of the mother. The progeny of fem-1(e2105) homozygotes develop as females at $25^{\circ} \mathrm{C}$ (Hodgkin 1986). Embryos deposited on a second plate were subjected to a $1-\mathrm{hr}$ heat shock at $33^{\circ} \mathrm{C}$, followed by 20 min at $20^{\circ} \mathrm{C}$, followed by $1 \mathrm{hr}$ at $33^{\circ} \mathrm{C}$. The same heat treatment was repeated at intervals of $18 \mathrm{hr}$. Animals were maintained at $25^{\circ} \mathrm{C}$ at other times. Heat-shocked transgenic animals de- scended from fem-2 homozygotes were scored for heat shockinduced masculinization upon reaching maturity. The total numbers of masculinized animals observed with a dissecting microscope (40x magnification) are listed in column 5 of Table 2. Samples of masculinized animals were examined by Nomarski microscopy (400 $\times$ magnification) to determine the extent of male development in various tissues (Table 2 , columns $6-11$ ). The following features were taken as indicative of masculinization: an asymmetric, unilobed somatic gonad; failure of vulval development, resulting in a pseudovulva or the complete absence of a vulva; presence of a tail fan, rays, or spicules; presence of sperm.

\section{Western blotting}

We assayed expression of HS-Myc-FEM-2 and its mutant derivatives by immunoblotting with monoclonal antibody 9E10. Twenty Rol, non-Dpy, non-Unc hermaphrodites carrying a given HS-Myc-FEM-2 transgene in the genetic background of strain AS204 were picked to each of two plates and allowed to lay eggs for 3-4 days. The progeny on one plate were then subjected to a $2-\mathrm{hr}$ heat shock at $33^{\circ} \mathrm{C}$ and allowed to recover for 2 $\mathrm{hr}$ at $25^{\circ} \mathrm{C}$. The other plate was incubated at $25^{\circ} \mathrm{C}$ continuously. Nematodes were harvested in M9 buffer, rinsed in M9 and again in water, and lysed by boiling in SDS sample buffer. Half of the resulting lysate was electrophoresed on an SDS polyacrylamide gel and transferred to nitrocellulose. Blotto [5\% skim milk powder in TBST: $25 \mathrm{~mm}$ Tris- $\mathrm{HCl}(\mathrm{pH} 7.5), 150 \mathrm{~mm} \mathrm{NaCl}$, and $0.2 \%$ Tween 20] was used for blocking blots and diluting antibodies, and washes were carried out with TBST (Harlow and Lane 1988). Monoclonal antibody $9 E 10$ was used as a 1:50 dilution of cell culture supernatant. Peroxidase-conjugated donkey antimouse secondary antibody (Jackson Laboratories) was used at a $1: 30,000$ dilution, and it was detected using the ECL system (Amersham).

\section{Acknowledgments}

We are grateful to J. Kimble for providing a fem-3 cDNA clone, R. Barstead for the gift of his $\lambda A C T$ C. elegans cDNA library, S. Elledge for providing vectors and strains for the two-hybrid screen, A. Fire for the heat-shock promoter plasmid, and W. Trimble for the 9E10 cell culture supernatant. We thank Jeb Gaudet and Dave Lum for their assistance in preparing the figures, and we are grateful to B. Andrews, J. Culotti, M. Perry, and M. Tyers for their helpful comments on the manuscript. I.C.-S. holds an Ontario Graduate Scholarship. This research was supported by the Medical Research Council of Canada.

The publication costs of this article were defrayed in part by payment of page charges. This article must therefore be hereby marked "advertisement" in accordance with 18 USC section 1734 solely to indicate this fact.

\section{References}

Ahringer, J. and J. Kimble. 1991. Control of the sperm-oocyte switch in Caenorhabditis elegans hermaphrodites by the fem-3 3' untranslated region. Nature 349: 346-348.

Ahringer, I., T.A. Rosenquist, D.N. Lawson, and J. Kimble. 1992. The Caenorhabditis elegans sex determining gene fem-3 is regulated post-transcriptionally. EMBO J. 11: 23032310.

Ausubel, F.M., R. Brent, R.E. Kingston, D.D. Moore, J.G. Seidman, J.A. Smith, and K. Struhl. 1989. Current protocols in molecular biology, Vol. 2. Wiley-Interscience, New York, NY. 
Bardwell, V.J. and R. Treisman. 1994. The POZ domain: A conserved protein-protein interaction motif. Genes \& Dev. 8: 1664-1677.

Barton, M.K. and J. Kimble. 1990. fog-1, a regulatory gene required for specification of spermatogenesis in the germ line of Caenorhabditis elegans. Genetics 125: 29-39.

Barton, M.K., T.B. Schedl, and J. Kimble. 1987. Gain-of-function mutations of fem-3, a sex-determination gene in Caenorhabditis elegans. Genetics 115: 107-119.

Brenner, S. 1974. The genetics of Caenorhabditis elegans. Genetics 77: 71-94.

Browning, H. and S. Strome. 1996. A sperm-supplied factor required for embryogenesis in C. elegans. Development 122: 391-404.

Church, D.L., K.L. Guan, and E.J. Lambie. 1995. Three genes of the MAP kinase cascade, mek-2, mpk-1/sur-1 and let-60 ras, are required for meiotic cell cycle progression in Caenorhab. ditis elegans. Development 121: 2525-2535.

Cohen, P. 1989. The structure and regulation of protein phosphatases. Annu. Rev. Biochem. 58: 453-508.

Cunningham, B.C. and J.A. Wells. 1989. High-resolution epitope mapping of hGH-receptor interactions by alaninescanning mutagenesis. Science 244: 1081-1085.

Dalton, S. and R. Treisman. 1992. Characterization of SAP-1, a protein recruited by serum response factor to the $c$-fos serum response element. Cell 68: 597-612.

De Bono, M., D. Zarkower, and J. Hodgkin. 1995. Dominant feminizing mutations implicate protein-protein interactions as the main mode of regulation of the nematode sexdetermining gene tra-1. Genes \& Dev. 9: 155-167.

Doniach, T. and J. Hodgkin. 1984. A sex-determining gene, fem1 , required for both male and hermaphrodite development in Caenorhabditis elegans. Dev. Biol. 106: 223-235.

Durfee, T., K. Becherer, P.L. Chen, S.H. Yeh, Y.Z. Yang, A.E. Kilburn, W.H. Lee, and S.J. Elledge. 1993. The retinoblastoma protein associates with the protein phosphatase type-1 catalytic subunit. Genes \& Dev. 7: 555-569.

Elledge, S.J., J.T. Mulligan, S.W. Ramer, M. Spottswood, and R.W. Davis. 1991. Lambda YES: A multifunctional cDNA expression vector for the isolation of genes by complementation of yeast and Escherichia coli mutations. Proc. Natl. Acad. Sci. 88: 1731-1735.

Ellis, R.E. and J. Kimble. 1995. The fog-3 gene and regulation of cell fate in the germ line of Caenorhabditis elegans. Genetics 139: 561-577.

Evan, G.I., G.K. Lewis, G. Ramsay, and J.M. Bishop. 1985. Isolation of monoclonal antibodies specific for human $c$-myc proto-oncogene product. Mol. Cell. Biol. 5: 3610-3616.

Fields, S. and O. Song. 1989. A novel genetic system to detect protein-protein interactions. Nature 340: 245-246.

Harlow, E. and D. Lane. 1988. Antibodies, a laboratory manual. Cold Spring Harbor Laboratory, Cold Spring Harbor, NY.

Hodgkin, J. 1986. Sex determination in the nematode C. elegans: Analysis of tra-3 suppressors and characterization of fem genes. Genetics 114: 15-52.

-1987. A genetic analysis of the sex-determining gene, tra-1, in the nematode Caenorhabditis elegans. Genes \& Dev. 1: 731-745.

-1988. Sexual dimorphism and sex determination. In The nematode Caenorhabditis elegans (ed. W.B. Wood), pp. 243279. Cold Spring Harbor Laboratory, Cold Spring Harbor, NY.

1992. Sex determination in the nematode Caenorhabditis. Sem. Dev. Biol. 3: 307-317.

Hodgkin, J., H.R. Horvitz, and S. Brenner. 1979. Nondisjunction mutants of the nematode Caenorhabditis elegans. Genetics 91: 67-94.

Hodgkin, J., M. Edgley, D. Riddle, and D.G. Albertson. 1988. Genetics. In The nematode Caenorhabditis elegans (ed. W.B. Wood), pp. 491-584. Cold Spring Harbor Laboratory, Cold Spring Harbor, NY.

Hunter, C.P. and W.B. Wood. 1992. Evidence from mosaic analysis of the masculinizing gene her- 1 for cell interactions in C. elegans sex determination. Nature 355: 551-555.

Hunter, T. 1995. Protein kinases and phosphatases: The yin and yang of protein phosphorylation and signaling. Cell 80: 225236.

Kimble, J., L. Edgar, and D. Hirsh. 1984. Specification of male development in Caenorhabditis elegans: The fem genes. Dev. Biol. 105: 234-239.

Kolodziej, P.A. and R.A. Young. 1991. Epitope tagging and protein surveillance. Methods Enzymol. 194: 508-519.

Kunkel, T.A., J.D. Roberts, and R.A. Zakour. 1987. Rapid and efficient site-specific mutagenesis without phenotypic selection. Methods Enzymol. 154: 367-382.

Kuwabara, P.E. and J. Kimble. 1992. Molecular genetics of sex determination in C. elegans. Trends Genet. 8: 164-168.

- 1995. A predicted membrane protein, TRA-2A, directs hermaphrodite development in Caenorhabditis elegans. Development 121: 2995-3004.

Kuwabara, P.E., P.G. Okkema, and J. Kimble. 1992. tra-2 encodes a membrane protein and may mediate cell communication in the Caenorhabditis elegans sex determination pathway. Mol. Biol. Cell 3: 461-473.

Leung, I., M. Bouvier-Durand, P. Morris, D. Guerrier, F. Chefdor, and I. Giraudat. 1994. Arabidopsis ABA response gene ABIl: Features of a calcium-modulated protein phosphatase. Science 264: 1448-1452.

McGowan, C.H. and P. Cohen. 1988. Protein phosphatase 2C from rabbit skeletal muscle and liver: $\mathrm{An} \mathrm{Mg}^{2+}$-dependent enzyme. Methods Enzymol. 159: 416-426.

Madl, J.E. and R.K. Herman. 1979. Polyploids and sex determination in Caenorhabditis elegans. Genetics 93: 393-402.

Maeda, T., A.Y.M. Tsai, and H. Saito. 1993. Mutations in a protein tyrosine phosphatase gene (PTP2) and a protein serine/threonine phosphatase gene (PTC1) cause a synthetic growth defect in Saccharomyces cerevisiae. Mol. Cell. Biol. 13: 5408-5417.

Maeda, T., S.M. Wurgler-Murphy, and H. Saito. 1994. A twocomponent system that regulates an osmosensing MAP kinase cascade in yeast. Nature 369: 242-245.

Mello, C. and A. Fire. 1995. DNA transformation. In Methods in cell biology: Caenorhabditis elegans: Modern biological analysis of an organism (ed. H.F. Epstein and D.C. Shakes), pp. 451-482. Academic Press, San Diego, CA.

Mello, C.C., J.M. Kramer, D. Stinchcomb, and V. Ambros. 1991. Efficient gene transfer in C. elegans: Extrachromosomal maintenance and integration of transforming sequences. EMBO I. 10: 3959-3970.

Meyer, K., M.P. Leube, and E. Grill. 1994. A protein phosphatase $2 \mathrm{C}$ involved in ABA signal transduction in Arabidopsis thaliana. Science 264: 1452-1455.

Michaely, P. and V. Bennett. 1992. The ANK repeat: A ubiquitous motif involved in macromolecular recognition. Trends Cell Biol. 2: 127-129.

Norman, C., M. Runswick, R. Pollock, and R. Treisman. 1988. Isolation and properties of cDNA clones encoding SRF, a transcription factor that binds to the $c$-fos serum response element. Cell 55: 989-1003.

Perry, M.D., W.Q. Li, C. Trent, B. Robertson, A. Fire, J.M. Hage- 
man, and W.B. Wood. 1993. Molecular characterization of the her-1 gene suggests a direct role in cell signaling during Caenorhabditis elegans sex determination. Genes \& Dev. 7: 216-228.

Pilgrim, D., A. McGregor, P. Jackle, T. Johnson, and D. Hansen. 1995. The C. elegans sex-determining gene fem-2 encodes a putative protein phosphatase. Mol. Biol. Cell 6: 1159-1171.

Roehl, H. and J. Kimble. 1993. Control of cell fate in C. elegans by a GLP-1 peptide consisting primarily of ankyrin repeats. Nature 364: 632-635.

Sanger, F., S. Nicklen, and A.R. Coulson. 1977. DNA sequencing with chain-terminating inhibitors. Proc. Natl. Acad. Sci. 74: 5463-5467.

Schiestl, R.H. and R.D. Gietz. 1989. High efficiency transformation of intact yeast cells using single stranded nucleic acids as a carrier. Curr. Genet. 16: 339-346.

Shenolikar, S. 1994. Protein serine/threonine phosphatasesNew avenues for cell regulation. Annu. Rev. Cell Biol. 10: $55-86$.

Sherman, F. 1991. Getting started with yeast. Methods Enzymol. 194: 3-21.

Shiozaki, K. and P. Russell. 1995. Counteractive roles of protein phosphatase 2C (PP2C) and a MAP kinase kinase homolog in the osmoregulation of fission yeast. EMBO /. 14: 492-502.

Spence, A.M., A. Coulson, and J. Hodgkin. 1990. The product of fem-1, a nematode sex-determining gene, contains a motif found in cell cycle control proteins and receptors for cell-cell interactions. Cell 60: 981-990.

Stinchcomb, D.T., J.E. Shaw, S.H. Carr, and D. Hirsh. 1985. Extrachromosomal DNA transformation of Caenorhabditis elegans. Mol. Cell. Biol. 5: $3484-3496$.

Stone, J.M., M.A. Collinge, R.D. Smith, M.A. Horn, and J.C. Walker. 1994. Interaction of a protein phosphatase with an Arabidopsis serine-threonine receptor kinase. Science 266: 793-795.

Stringham, E.G., D.K. Dixon, D. Jones, and E.P.M. Candido. 1992. Temporal and spatial expression patterns of the small heat shock (hsp-16) genes in transgenic Caenorhabditis elegans. Mol. Biol. Cell 3: 221-233.

Sulston, I.E. and J.A. Hodgkin. 1988. Methods. In The nematode Caenorhabditis elegans (ed. W.B. Wood), pp. 587-606. Cold Spring Harbor Laboratory, Cold Spring Harbor, NY.

Trent, C., B. Purnell, S. Gavinski, J. Hageman, C. Chamblin, and W.B. Wood. 1991. Sex-specific transcriptional regulation of the C. elegans sex-determining gene her-1. Mech. Dev. 34: 43-56.

Villeneuve, A.M. and B.J. Meyer. 1990a. The regulatory hierarchy controlling sex determination and dosage compensation in C. elegans. Adv. Genet. 27: 117-188.

- $1990 \mathrm{~b}$. The role of $s d c-1$ in the sex determination and dosage compensation decisions in Caenorhabditis elegans. Genetics 124: 91-114.

Zarkower, D. and J. Hodgkin. 1992. Molecular analysis of the $C$. elegans sex-determining gene tra-1: A gene encoding two zinc finger proteins. Cell 70: 237-249.

- 1993. Zinc fingers in sex determination: Only one of the two C. elegans Tra-1 proteins binds DNA in vitro. Nucleic Acids Res. 21: 3691-3698. 


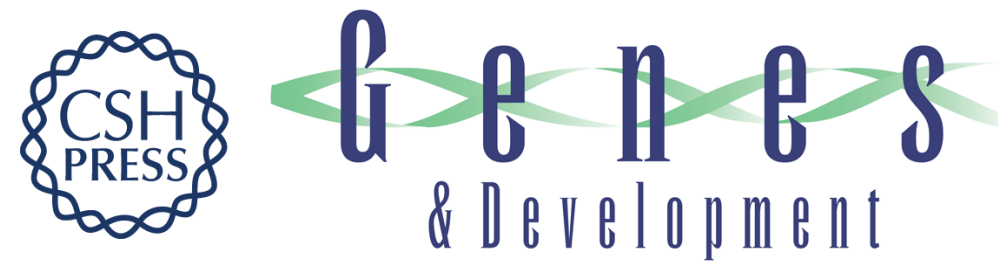

\section{Caenorhabditis elegans sex-determining protein FEM-2 is a protein phosphatase that promotes male development and interacts directly with FEM-3.}

I D Chin-Sang and A M Spence

Genes Dev. 1996, 10:

Access the most recent version at doi:10.1101/gad.10.18.2314

References This article cites 56 articles, 28 of which can be accessed free at:

http://genesdev.cshlp.org/content/10/18/2314.full.html\#ref-list-1

License

Email Alerting Service

Receive free email alerts when new articles cite this article - sign up in the box at the top right corner of the article or click here.

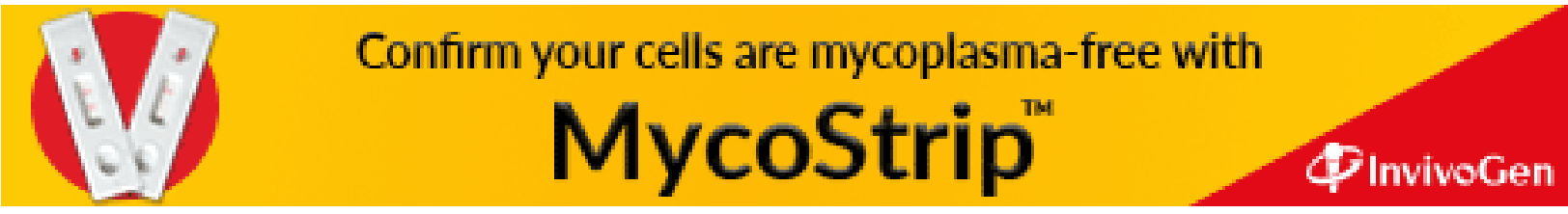

